\title{
Business Simulation, Student Competency, And Learning Outcomes
}

\author{
Christiana Fara Dharmastuti ${ }^{1}$, Syarief Darmoyo ${ }^{2}$, \\ Reinandus Aditya Gunawan ${ }^{3}$, Maria Natasya Duka ${ }^{4}$ \\ 1,2,3,4 Fakultas Ekonomi dan Bisnis, Universitas Katolik Indonesia Atma Jaya Jakarta \\ Email address: \\ christiana.fara@atmajaya.ac.id*;syarief.darmoyo@atmajaya.ac.id; \\ aditya.gunawan@atmajaya.ac.id; tasyaduka5@gmail.com
}

\begin{abstract}
The shifting paradigm in the learning process changes with technological advances and the internet. The learning process is through conventional classes with teacher center learning and is changing towards student center and experiential learning. Unika Atma Jaya's management program develops learning using IT platforms for business simulations to train students' way of thinking about business processes within the company virtually. This study wants to examine how a business simulation class student's experience impacts student business competency and learning outcomes in learning Business Simulation. The results showed that student experience through perceived usefulness and perceived enjoyment affected learning outcomes mediated by student business competency.
\end{abstract}

Keywords: Business simulation, competency, learning outcome.

\begin{abstract}
Abstrak: Perubahan paradigma dalam proses pembelajaran mahasiswa mengalami perubahan dengan kemajuan teknologi dan internet. Proses pembelajaran tidak hanya melalui kelas konvensional dengan teacher center learning tapi berubah ke arah student center learning maupun experiential learning. Prodi manajemen FEB Unika mengembangkan pembelajaran menggunakan platform IT untuk simulasi bisnis guna melatih cara berpikir mahasiswa mengenai proses bisnis di dalam perusahaan secara virtual. Penelitian ini ingin meneliti, bagaimana pengalaman mahasiswa kelas simulasi bisnis berdampak terhadap student business competency dan learning outcomes dalam pembelajaran Simulasi Bisnis. Hasil penelitian menunjukkan bahwa pengalaman mahasiswa melalui perceived usefulness \& perceived enjoyment berpengaruh terhadap learning outcomes dimediasi oleh student business competency.
\end{abstract}

Kata Kunci: Simulasi bisnis, kompetensi, capaian pembelajaran.

\section{INTRODUCTION}

Through effective communication systems and evolutions in various technologies, the trend of globalization has influenced business management and administration. Challenges are increasing in the practice of business education. Educational critics identify a large gap between the knowledge and skills required for the real world of business and the academic 
knowledge and skills acquired through education. The paradigm shift in the student learning process has changed in recent times, specifically related to advances in technology and the internet. The learning process is through conventional classrooms with teacher-centered learning in the classroom and has shifted to become student center learning. Conventional learning in the classroom tends to be more theoretical and less understanding of practices in the real business world. The development of technology and information encourages changes in the learning scenario, where the learning process will refer to technology's contribution. The improvement of technology in the world of work also encourages technology implementation in universities' lesson curriculum (Lim and Rubasundram, 2018).

In an increasingly developing world where volatility, uncertainty, complexity, and ambiguity (VUCA) occur, an essential factor in the world of work is the skill to adapt to a new world, not only knowledge content. Scholars to enter the world of work, it is essential to have Experiential Learning Theory (ELT) in the Education program, for example, using computer simulation games for the basis of business modeling. (Jonathan and Laik, 2019) ELT provides a contrasting learning experience - one academic institution is highly theorybased and typical, and the other leads to practice and skills.

(Farashahi and Tajeddin, 2018) the gap between business practice and the world of education raises attention to identify the most effective teaching methods to reduce gaps and develop professional skills. Various approaches such as action learning, practice-based learning, problem-based learning have begun to be developed. Simulation as an experiential learning method has received more attention among business educators among all these teaching methods.

One of the lessons that can be done is using a business simulation. (Mitchell, 2006), business simulation comes from two forms: a simulation created as a reflection of a specific business or described a general business model. By using business simulations, students are expected to understand business practices better and understand the relationship between business flows between departments within the company virtually. This method will invite students to develop the learning process, encourage an active role among groups and improve experiential learning through simulations at work (Hernandes et al., 2019).

The use of business simulation games plays an essential role in the teaching and learning process, even though it has been used for 60 years since modern business simulation games began in 1955. Business simulation is included in the competition, experience, analytical exercise, strategy, decision making, learning and objectives, collaboration and teamwork, motivation, application of theoretical concepts, active learning, integration of ideas, and all of these elements are made fun and enjoyable (Chai, 2018). Gamification of games in the learning approach will motivate and influence participant behavior to achieve learning outcomes (Aries et al., 2020).

In 2018, Atma Jaya Catholic University of Indonesia's Faculty of Economics and Business' management study program decided to collaborate with MonsoonSIM. A company provides a business simulation platform. It is crucial to describe and train students' thinking about business processes within the company through the business simulation method. (Zulfiqar et al., 2019) stated that learning through business simulations is very useful, easy, and engaging, helping students think critically. This method requires a movement from traditional classroom system methods to learning-based methods that help students engage in practice to imply existing theories. 
The application of business simulations in the Unika Atma Jaya management study program is expected to bring a new atmosphere and learning methods for students that encourage them to be more active, participative, collaborating with experiential learning in the business world even though virtually. (Hernandes et al., 2019), referring to several previous studies, stated that even though there are benefits, there are still criticisms about the effectiveness in improving student learning outcomes. Among others depending on the learning methodology, the existence of different roles of lecturers no longer centered on the transmission of knowledge but more as a facilitator, collaborator, advisor, moderator, and coach in learning. It is further stated that student opinions and perceptions are essential in understanding the learning process and results. Often, lecturers will leave learning, and the process is carried out by students themselves or their groups.

(Asiri et al., 2017), in their study, found that students who have experience doing business simulations are more easily accepted to work. Given the importance of the learning process that pays attention to the development of times and technology and provides practical world experience, this study aims to analyze whether the MonsoonSIM platform used by the Atma Jaya FEB Management Study Program has an impact on students' understanding of the business learning process.

Specifically, this study examines how student experience is measured by perceived usefulness, ease of use \& perceived enjoyment in using a simulation platform on student business competency, and learning outcomes in Business Simulation learning. This approach was chosen considering that business simulations use a technology platform that often creates negative and positive perceptions. Therefore, if the user believes that the system's use will improve his job performance, it will motivate him to continue using it. (Mohd et al., 2018)

We consider this study necessary because the learning process variation is still limited. Studies on the impact of business simulations on learning processes and outcomes are still very limited in Indonesia. This study's results are expected to provide input to the academic world, especially the Faculty of Economics and Business in Indonesia.

Theoretical Framework. Learning using simulations is designed based on constructivist learning theory, where users will learn or build new knowledge from their scientific concepts (Zulfiqar et al., 2017). Simulation is a simple and attractive virtual system where students are given various forms and a risk-free environment to work together, discuss and make decisions based on particular situations. Meanwhile, simulation games have several rules and characteristics that students must follow to get the essence of working in realitybased scenarios. Business simulation games are also known as economic simulation games that focus on managing economic business processes.

(Gatti et al., 2019) stated that besides being able to be used by students to understand business processes in the real world better, business simulations could also support the sustainability of education itself. In line with the development of industry 4.0, business simulations can support the sustainability of a university. The continuity of higher education requires learning that enhances employability into the curriculum, to bridge the gap between theory and practice, between the skills possessed and the skills needed by the industry. (Chai, 2018)

The use of business simulations also supports student careers if they later choose to work in a company. According to (Asiri et al., 2017), students who study at universities with 
business simulation courses are found to be easier to be accepted into a company than those without business simulation experience. Of course, this is advantageous for a university if it has business simulation courses in its curriculum.

Business simulations can also train students' attitudes towards making business decisions in companies, whether they dare to take risks or not (Zulfiqar et al., 2019). Of course, more students are trained to make decisions, and it will be beneficial if later students are becoming entrepreneurs. This decision-making exercise is undoubtedly challenging to learn if students only take traditional teaching courses compared to students who have studied decision-making through business simulations. Also, the use of business simulations increases student motivation in the learning process. (Lin et al., 2018).

(Zulfigar et al., 2017) state several essential characteristics in simulations, namely: a) students interact actively in real complex life situations, b) there are rules, regulations, and responsibilities c) implementation of different strategies in specific environments d) trying to adjust for changes while trying to improve performance in the simulation system. (Clarke, 2009) states that business simulations can have different characteristics as a) micro-world simulations, which emphasize the area of business functions b) macro world simulations, which cover complex system problems between companies/industries represented by teams or participants c) interpersonal skills simulations, which focus on practical training of various interpersonal scenarios with the team regarding customer problems, critical decision-making skills, operations, and induction d) business acumen simulations, focusing on developing skills in strategy formulation, allocating scarce resources, developing products and services, fulfill customer needs, manage finances, and compete with other businesses.

(Harold et al., 2016) suggest that the main challenge when modeling behavior used in games is to summarize game users' knowledge, skills, and attributes (KSA-knowledge, skills \& attributes). In KSA, user attributes are not knowledge or skills but are user properties that can be changed, such as attitudes, influences, interests, and preferences. KSA allows (1) to include other attributes, such as, for example, mental or physical health, (2) to resolve some ambiguity between abilities and skills, and (3) to include various learning or mental factors or physiological changes in the model. These factors are essential because games present a highly nonlinear assessment or learning experience and therefore require accurate validation of the resulting computational model and the processes and assumptions used to produce this model.

Student understanding can be measured; several indicators can be used; according to (Lim and Rubasundram, 2018), to measure student understanding, 4C can be used, namely critical thinking, collaboration, communication, \& creativity. (Jonathan and Laik, 2019) use VUCA, namely volatility, uncertainty, complexity \& ambiguity. This study will use the approach (Mohd et al., 2018) in measuring student understanding using perceived usefulness, perceived ease of use \& perceived enjoyment. This approach was chosen considering that technology often creates both negative and positive feelings when using technology, especially the system being developed. Therefore, if the user believes that the system's use will improve his job performance, it will motivate him to continue using it.

According to (Davis, 1989), (Mohd et al., 2018) perceived usefulness as a person's belief that using a unique system will improve his job performance. If the use of technology is in doubt, there will be no one's intention to use it. Perceived ease of use is a perception of the ease of use of technology. The extent to which a person believes that using technology 
will be free from difficulties. Perceived enjoyment is an intrinsic motivation for an exciting activity, and enjoyment is felt and fun activities in a game.

Based on the studies that have been carried out, this study will examine perceptions based on students' experiences in participating in business simulation learning and their effects on their competencies and learning outcomes. Based on the discussion above, the hypothesis is proposed as follows:

H1: Perceived usefulness influences Student Business Competency.

H2: Perceived ease of use influences Student Business Competency.

H3: Perceived enjoyment influences Student Business Competency.

H4: Student Business Competency influences perceived learning outcomes.

H5: Student Business Competency acts as a mediating variable.

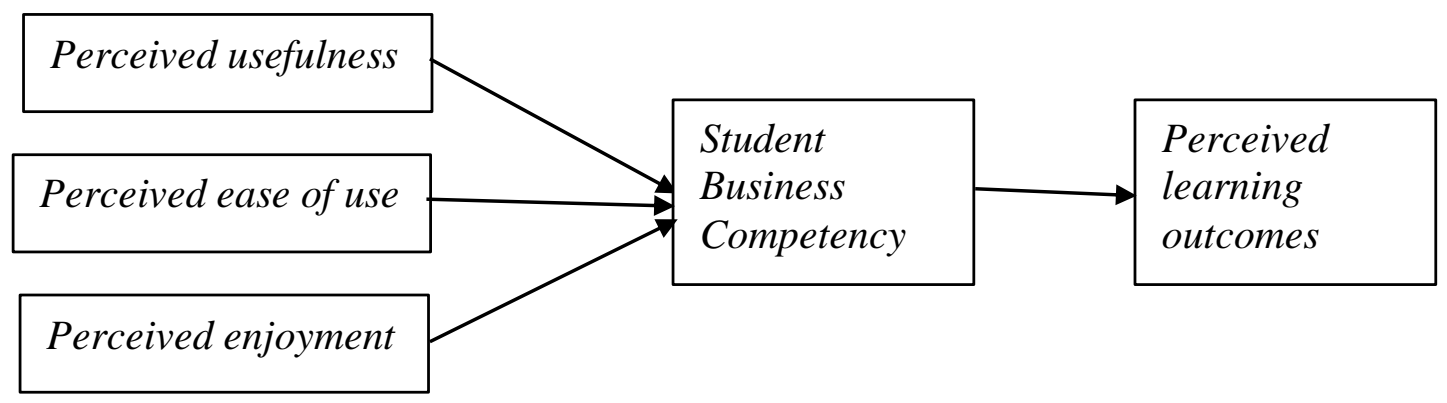

Figure 1. Research Model

\section{METHODS}

The data used in this study will use primary data from questionnaires distributed to respondents. This study's population were all students who had and are currently taking Business Simulation courses at the Faculty of Economics and Business, Atma Jaya University Jakarta. Based on the data obtained, 83 complete data can be used for research. Primary data using a questionnaire with a Likert scale measurement on a scale of 1-7.

To measure student experience will use the approach according (Mohd et al., 2018). Student understanding based on perception divided into three, namely perceived usefulness, is the benefits students feel when using a business simulation learning system implemented in the class, measured through 5 questionnaire questions. Perceived ease of use is perceived ease of use of a simulation system, where students believe in the mental and physical effort required to use the system, measured through 5 questions in the questionnaire. Perceived enjoyment is a perception of intrinsic motivation, which implies an exciting activity; enjoyable enjoyment is carried out in education because the simulation is often seen as a game, measured through 6 questionnaire questions.

Student Business Competency uses an approach (Hernandes et al., 2019) that measures generic competencies and managerial competencies obtained through business simulation learning by ignoring the methodology used. Student competence is divided into generic competence (GB) and specific managerial competence (SC) and is measured through 12 questionnaire questions. Perceived learning outcomes are student perceptions/opinions on students' learning outcomes based on student values, satisfaction, 
and expectations on how they can improve their knowledge and learning often referred to as student performance, measured through 7 questionnaire questions.

Data analysis was performed using SEM-PLS because the data was minimal and the data were not normally distributed. According to (Hair et al., 2014), SEM-PLS can be used in research where the data is not normal, the sample size is small, and the construct is measured both formatively and reflectively.

\section{RESULTS AND DISCUSSION}

Data collection results using a questionnaire obtained 83 data that can be used for further analysis. The following is descriptive data from the demographic data of the respondents.

Table 1. Respondents' Characteristic

\begin{tabular}{l|l|l|l}
\hline & & $\Sigma$ & $\%$ \\
\hline Gender & Woman & 41 & 49,4 \\
\hline & Man & 42 & $\mathbf{5 0 , 6}$ \\
\hline Major & Marketing & 22 & 26,5 \\
\hline & Finance & 18 & 21,7 \\
\hline & HRM & 13 & 15,7 \\
\hline GPA & Business & 30 & $\mathbf{3 6 , 1}$ \\
\hline & $<2.50$ & 2 & 2,4 \\
\hline & $2.50-3.00$ & 23 & 27,7 \\
\hline & $3.01-3.50$ & 34 & $\mathbf{4 1 , 0}$ \\
\hline
\end{tabular}

Based on table 1, it can be seen that the respondents have an almost balanced composition between man and woman. Most respondents who took business simulation courses from a business interest were $36.1 \%$, with the highest GPA of $41 \%$ between 3.01 4.00.

Table 2. Correlation between Gender, GPA, Specialization with Perceived Usefulness, Perceived Ease, Perceived Enjoyment, Student Business Competency

\begin{tabular}{|c|c|c|c|c|}
\hline & \multirow{2}{*}{$\begin{array}{l}\text { Gender } \\
\mathrm{r}^{\mathrm{a}}\end{array}$} & \multirow{2}{*}{$\begin{array}{l}\text { GPA } \\
r^{b}\end{array}$} & \multicolumn{2}{|l|}{ Major } \\
\hline & & & $\chi^{2 \mathrm{c}}$ & $\mathrm{CC}$ \\
\hline Perceived Usefulness & ,043 & , 155 & 5,792 & ,279 \\
\hline Perceived Ease & ,145 &,- 076 & 2,480 & , 165 \\
\hline Perceived Enjoyment &,- 009 & ,117 & 3,488 & ,234 \\
\hline Student Business Competency & ,192+ & ,175 & $14,018 *$ & ,395* \\
\hline
\end{tabular}

Notes: ${ }^{\mathrm{a} B i s e r i a l}$ correlation; ${ }^{\mathrm{b}}$ Spearman correlation; ${ }^{\mathrm{c}} \mathrm{Chi}$ square test; IPK indeks prestasi kumulatif; ${ }^{+} \mathrm{p}<0.1 ; * \mathrm{p}<0,05 ; \mathrm{CC}$ coefficient contingency 
Based on the results of table 2, it provides information that the correlation between the demographic data of respondents: gender, GPA, specialization does not correlate with the variables studied. However, one demographic variable, namely the type of student interest (major), strongly correlates with student business competency (SBC).

Table 3. Results of crosstab between specialization and Student Business Competency

\begin{tabular}{|c|c|c|c|c|c|}
\hline & \multicolumn{4}{|c|}{ Major } \\
\hline & & Marketing & Finance & HRM & Business \\
\hline & & $\overline{\mathrm{f}(\%)}$ & $\overline{\mathrm{f}(\%)}$ & $\mathrm{f}(\%)$ & $\overline{\mathrm{f}(\%)}$ \\
\hline \multirow{4}{*}{$\begin{array}{l}\text { Student Competency } \\
\text { Business }\end{array}$} & Low & $0(0,0)$ & $0(0,0)$ & $1(7,7)$ & $4(13,3)$ \\
\hline & Moderate & $18(81,8)$ & $7(38,9)$ & $5(38,5)$ & $13(43,3)$ \\
\hline & High & $\underline{4(18,2)}$ & $\underline{11(61,1)}$ & $\underline{7(53,8)}$ & $13(43,3)$ \\
\hline & & $22(100)$ & $18(100)$ & $13(100)$ & $30(100)$ \\
\hline
\end{tabular}

Note: SDM sumber daya manusia

Further analysis of the results of the correlation in Table 2 shows that based on the type of field of study, the respondents who have the highest percentage of SBC are in financial interests of $61.1 \%$, while the SBC in the moderate group is in marketing specializations. Low SBC is not there for specialization marketing and finance, while respondents who have low SBC are interested in Business and HRM.

Table 4. Outer model evaluation

\begin{tabular}{|c|c|c|c|}
\hline & & $\begin{array}{l}\text { Outer } \\
\text { Loading }\end{array}$ & t-value \\
\hline \multicolumn{4}{|c|}{ Perceived Usefulness (C.A.= 0,914; C.R.= 0,936; AVE= 0,744) } \\
\hline PU1 & $\begin{array}{l}\text { Using a business simulation application improves my learning } \\
\text { outcomes. }\end{array}$ & 0,900 & $40,058 *$ \\
\hline PU2 & $\begin{array}{l}\text { The use of business simulation applications in the curriculum } \\
\text { allows me to study more efficiently and effectively. }\end{array}$ & 0,845 & $21,740^{*}$ \\
\hline PU3 & I believe that content in business simulations is useful & 0,841 & $22,884 *$ \\
\hline PU4 & $\begin{array}{l}\text { Practicing business simulation made me understand the theory } \\
\text { that I was studying }\end{array}$ & 0,873 & $23,253 *$ \\
\hline PU5 & $\begin{array}{l}\text { Business simulation practice helps me understand business } \\
\text { issues in the company }\end{array}$ & 0,852 & $20,648 *$ \\
\hline \multicolumn{4}{|c|}{ Perceived Ease $($ C.A. $=0,870 ;$ C.R.= 0,911; AVE= 0,720 $)$} \\
\hline PE2 & $\begin{array}{l}\text { The operation of the business simulation system is easy for me to } \\
\text { do }\end{array}$ & 0,795 & $15,992 *$ \\
\hline PE3 & I easily understand the business simulation process & 0,854 & $23,654 *$ \\
\hline PE4 & I have no trouble studying the system in a business simulation & 0,873 & $30,936^{*}$ \\
\hline PE5 & The content in business simulation applications is easy to learn & 0,869 & $27,108 *$ \\
\hline \multicolumn{4}{|c|}{ Perceived Enjoyment $($ C.A.= 0,832; C.R.= 0,899; AVE= 0,749) } \\
\hline $\mathrm{PJ} 2$ & Business simulation is very interesting for me & 0,853 & $14,287 *$ \\
\hline $\mathrm{PJ} 3$ & $\begin{array}{l}\text { I feel like looking for more information when studying business } \\
\text { simulations }\end{array}$ & 0,870 & $20,916^{*}$ \\
\hline PJ5 & I enjoy learning to use business simulations & 0,872 & $26,153 *$ \\
\hline
\end{tabular}

Student Business Competency (C.A.= 0,925; C.R.= 0,937; AVE= 0,598) 


\begin{tabular}{|c|c|c|c|}
\hline SBC1 & I can analyze the information & 0,810 & $25,005^{*}$ \\
\hline $\mathrm{SBC} 2$ & I am capable of making meaningful decisions & 0,711 & $8,684^{*}$ \\
\hline $\mathrm{SBC} 3$ & I can relate the existing information & 0,740 & $9,642^{*}$ \\
\hline SBC5 & I am capable of time management & 0,824 & $18,538 *$ \\
\hline SBC6 & I can solve problems and work-related to deadlines & 0,811 & $19,229 *$ \\
\hline SBC7 & I am driven to learn to use new technology & 0,801 & $13,859 *$ \\
\hline SBC8 & I can solve technical problems in the technology used & 0,796 & $18,908 *$ \\
\hline SBC9 & I can resolve conflicts in groups & 0,781 & $15,785^{*}$ \\
\hline SBC11 & I became more creative & 0,740 & $13,672 *$ \\
\hline SBC13 & I accept the opinions and influences of others & 0,709 & $11,692 *$ \\
\hline \multicolumn{4}{|c|}{ erceived Learning Outcomes (C.A.= 0,909; C.R.= 0,928; AVE= 0,648) } \\
\hline PLO1 & My participation as an individual in the simulation is significant & 0,790 & $12,688 *$ \\
\hline PLO2 & My participation as part of the group is significant & 0,719 & $9,291 *$ \\
\hline PLO3 & I achieve goals and targets by participating in simulation games & 0,809 & $19,872 *$ \\
\hline PLO4 & $\begin{array}{l}\text { Business simulations make a real contribution to the experiential } \\
\text { learning process for me }\end{array}$ & 0,881 & $34,753 *$ \\
\hline PLO5 & Business simulation enhances personal skills & 0,810 & $18,804 *$ \\
\hline PLO6 & $\begin{array}{l}\text { Business simulations provide an understanding of existing } \\
\text { business practices }\end{array}$ & 0,772 & $8,353^{*}$ \\
\hline PLO7 & I am satisfied with this learning experience & 0,847 & $23,272 *$ \\
\hline
\end{tabular}

Table 5. Discriminant Validity

\begin{tabular}{lllll}
\hline & $(1)$ & $(2)$ & $(3)$ & $(4)$ \\
\hline PU & $\mathbf{0 , 7 2 6}$ & & & \\
PE & CI.95 $[0,496 ; 0,880]$ & & & \\
& $\mathbf{0 , 8 3 4}$ & $\mathbf{0 , 8 5 4}$ & & \\
PJ & CI.95 $[0,684 ; 0,941]$ & CI.95 $[0,722 ; 0,961$ & & \\
& $\mathbf{0 , 7 9 3}$ & $\mathbf{0 , 7 4 4}$ & $\mathbf{0 , 8 3 3}$ & \\
SBC & CI.95 $[0,668 ; 0 ; 896]$ & CI.95 $[0,584 ; 0,862]$ & CI.95 $[0,719 ; 0,946]$ & \\
& $\mathbf{0 , 8 1 8}$ & $\mathbf{0 , 6 9 1}$ & $\mathbf{0 , 9 1 3}$ & $\mathbf{0 , 9 0 9}$ \\
PLO & CI $.95[0,682 ; 0,924]$ & CI.95 $[0,516 ; 0,819$ & CI.95 $[0,809 ; 1,003]$ & CI.95 $[0,831 ;$ \\
& P. & & & $0,969]$ \\
\hline
\end{tabular}

Note: PU perceived usefulness, PJ perceived enjoyment, PE perceived ease, SBC student business competency, PLO perceived learning outcomes

Based on table 4, it can be seen that all the constructs of this study have good internal consistency reliability because their CA and CR values are> 0.70 . All the constructs of this study have good convergent validity because the outer loading value is $>0.70$ and is significant at $\mathrm{p}<0.001$, and the AVE value $>0.50$. Furthermore, from table 5, all the constructs of this study have good discriminant validity because, at the $90 \%$ confidence interval, the values for all relationships between constructs do not include a value of 1 . The results above show that all the indicators of this study are reliable and valid. 
Table 6. Collinearity

\begin{tabular}{lll}
\hline Independent variable & Dependent Variable & Inner VIF \\
\hline Perceived Usefulness & Student Business Competency & 2,269 \\
Perceived Ease & Student Business Competency & 2,240 \\
Perceived Enjoyment & Student Business Competency & 2,777 \\
Student Business Competency & Perceived Learning Outcomes & 2,795 \\
\hline
\end{tabular}

Before conducting further testing, an assessment of the collinearity between independent variables so that the estimated path coefficient is not biased shows that all inner VIF values for all independent variables are <5. If the internal variance inflation factor (VIF) value is $<5$, then the model does not have a collinearity problem between independent variables (Hair et al., 2017). Thus, the model does not have a collinearity problem between the independent variables.

SRMR is the difference in the observed correlation matrix and the correlation implied in the model. If the SRMR value $<0.10$ or 0.08 , the model is said to be good fit. Another way to assess this difference is to use the exact fit criteria: d_ULS and d_G. According to Dijkstra and Henseler (2015), if the original values of d_ULS and d_G are smaller than the upper limit at a certain confidence interval (95\% or 99\%) then the model is said to be good fit. Based on table 7, it can be seen that the SRMR value $<0.08$. Likewise, the original value d_ULS $(2,645)$ <bootstrapped HI 99\% $(2,719)$ and the original value d_G $(2,275)$ $<$ bootstrapped HI 99\% $(3,501)$ for d_G. Thus, this research model is good fit.

Table 7. Goodness of overall model fit measures

\begin{tabular}{lccc}
\hline & Original Sample (O) & $\mathbf{9 5 \%}$ & $\mathbf{9 9 \%}$ \\
\hline SRMR & $\mathbf{0 , 0 7 8}$ & 0,073 & $\mathbf{0 , 0 7 9}$ \\
d_ULS & $\mathbf{2 , 6 4 5}$ & 2,317 & $\mathbf{2 , 7 1 9}$ \\
d_G & $\mathbf{2 , 2 7 5}$ & 2,964 & $\mathbf{3 , 5 0 1}$ \\
\hline
\end{tabular}

Table 8. Summary of Direct Effects Tests

\begin{tabular}{lccccc}
\hline & $\begin{array}{c}\text { Path } \\
\text { coefficient }\end{array}$ & $\boldsymbol{t}$ Values & $\boldsymbol{p}$ Values & $\begin{array}{c}\mathbf{9 5 \%} \text { Confidence } \\
\text { Interval }\end{array}$ & $\begin{array}{c}\text { Significant } \\
(\mathbf{p}<\mathbf{0 , 0 5})\end{array}$ \\
\hline $\mathrm{H}_{1}$ : PU -> SBS & 0,372 & 3,055 & 0,002 & {$[0,126 ; 0,600]$} & Yes \\
$\mathrm{H}_{2}$ : PE -> SBS & 0,190 & 1,990 & 0,047 & {$[0,007 ; 0,379]$} & Yes \\
$\mathrm{H}_{3}:$ PJ $>$ SBS & 0,329 & 2,617 & 0,009 & {$[0,065 ; 0,553]$} & Yes \\
$\mathrm{H}_{4}$ : SBS -> PLO & 0,490 & 5,232 & 0,000 & {$[0,306 ; 0,671]$} & Yes \\
$\mathbf{R}^{2}$ Perceived Learning Outcomes $=0.789 ; \mathbf{Q}^{2}$ Perceived Learning Outcomes $=0,465$ & \\
$\mathbf{R}^{2}$ Student Business Competency $=0.642 ; \mathbf{Q}^{2}$ Student Business Competency $=0,345$ & \\
\hline
\end{tabular}

Note: PU perceived usefulness; PE perceived ease; PJ perceived enjoyment ; SBC student business competency; PLO perceived learning outcomes 


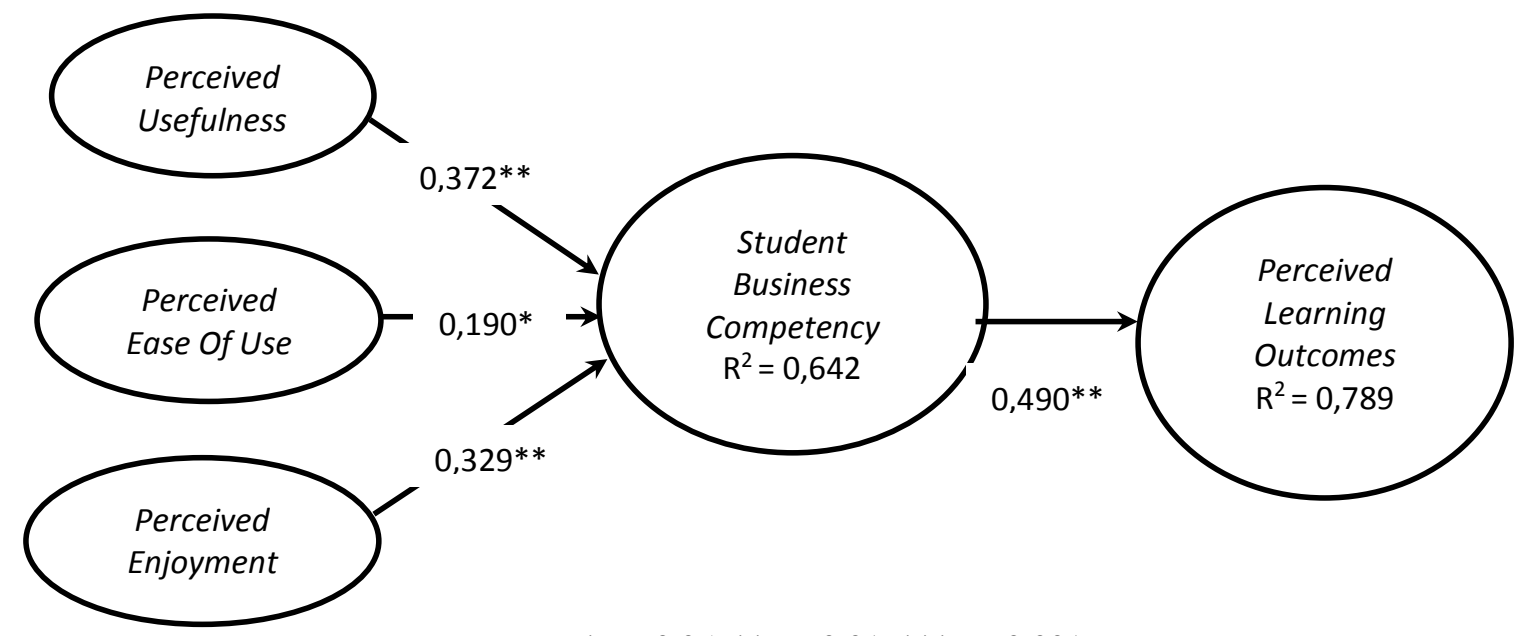

Note; $* \mathrm{p}<0,05, * * \mathrm{p}<0,01, * * * \mathrm{p}<0,001$

Figure 2. Analysis Result

The results of hypothesis testing 1 - 4 can be seen in Figure 2 and Table 8 . The R2 value for perceived learning outcomes is 0.789 , and for the student, business competency is 0.642 . The result shows that the variable perceived learning outcome variation can be explained by the student business competency variable of $78.9 \%$. In contrast, the variable perceived usefulness, perceived ease, and perceived enjoyment of $64.2 \%$ can explain the variation of the business competency variable. The value of R2 for the two dependent variables indicates that the level of prediction accuracy of each independent variable is classified as "strong" and "moderate." Table 8 shows that the Q2 value for perceived learning outcomes is 0.465 , while for student business competency, it is 0.345 . The value of Q2 is> than 0, which means that all exogenous constructs have considerable predictive relevance. (Hair et al., 2017).

Based on the data processing results in Figure 2 and Table 8, perceived usefulness has a positive and significant effect on student business competency $(\beta=0.372, p<0.05)$. Likewise, perceived ease positively and significantly affects student business competency $(\beta=0.190, p<0.05)$. Next, perceived enjoyment has a positive and significant effect on student business competency $(\beta=0.329, p<0.05)$. Finally, student business competency positively and significantly affects perceived learning outcomes $(\beta=0.490, \mathrm{p}<0.05)$. Accordingly, H1. H2. H3 and H4 accepted.

Table 9 illustrates the magnitude of the direct influence of the independent variable on the dependent variable. The table shows that the direct effect of perceived usefulness on student business competency is "moderate" student business competency. Meanwhile, the direct effect of perceived ease and perceived enjoyment on student business competency is classified as "weak." Likewise, student business competency's direct effect on perceived learning outcomes is classified as "weak." 
Table 9. $\mathrm{f}^{2}$ Effect Size

\begin{tabular}{llll}
\hline Independent variable & dependent variable & $\boldsymbol{f}^{2}$ & Total effect \\
\hline Perceived Usefulness & Student Business Competency & 0,17 & Moderate \\
Perceived Ease & Student Business Competency & 0,045 & Weak \\
Perceived Enjoyment & Student Business Competency & 0,109 & Weak \\
Student Business Competency & Perceived Learning Outcomes & 0,407 & Weak \\
\hline
\end{tabular}

This study also tested student business competency as a mediating variable for perceived usefulness, perceived ease, and perceived enjoyment for perceived learning outcomes. The analysis results in table 10 show that student business competency acts as a mediating variable on the effect of perceived usefulness on perceived learning outcomes ( $\beta$ $=0.182, p=0.003<0.05)$. Likewise, perceived enjoyment towards perceived learning outcomes $(\beta=0.161, p=0.032<0.05)$. Meanwhile, the indirect effect of perceived ease on perceived learning outcomes through student business competency is not significant $(\beta=$ $0.093, \mathrm{p}=0.065>0.05)$.

The mediating effect of student business competency can be classified as "partial mediation." The direct effect of perceived usefulness on perceived learning outcomes is significant $(\beta=0.183, p<0.05)$ and also perceived enjoyment $(\beta=0.382, p<0.05)$. This conclusion is reinforced by the results of the calculation of variance accounted for (VAF), which shows that the mediation effect of student business competency on the relationship between perceived usefulness (49.9\%) and perceived enjoyment $(29.7 \%)$ and perceived learning outcomes is of the type "partial mediation." Nitzl, Roldan, and Cepeda (2016) reveal that VAF determines the extent to which the mediation process explains variations in the dependent variable. If the VAF is less than $20 \%$, it can be concluded that there is no mediation; situations in which the VAF is greater than $20 \%$ and less than $80 \%$ can be defined as partial mediation; a VAF greater than $80 \%$ indicates full mediation.

Table 10. Summary of Mediating Effects Tests

\begin{tabular}{|c|c|c|c|c|c|c|}
\hline & $\begin{array}{l}\text { Path } \\
\text { coeff. }\end{array}$ & $t$ Values & $p$ Values & $\begin{array}{l}\text { 95\% Confidence } \\
\text { Interval }\end{array}$ & $\begin{array}{c}\text { Significant } \\
(\mathrm{p}<\mathbf{0 , 0 5})\end{array}$ & VAF \\
\hline \multicolumn{7}{|l|}{ Direct Effect } \\
\hline PU -> PLO & 0,183 & 2,077 & 0,038 & {$[0,009 ; 0,350]$} & Yes & \\
\hline PE -> PLO & $-0,104$ & 1,420 & 0,156 & {$[-0,255 ; 0,032]$} & No & \\
\hline PJ -> PLO & 0,382 & 3,844 & 0,000 & {$[0,191 ; 0,575]$} & Yes & \\
\hline \multicolumn{7}{|l|}{ Indirect Effect } \\
\hline $\mathrm{H}_{5}: \mathrm{PU}->\mathrm{SBC} \rightarrow \mathrm{PLO}$ & 0,182 & 2,941 & 0,003 & {$[0,073 ; 0,319]$} & Yes & $49, \%$ \\
\hline $\mathrm{H}_{6}: \mathrm{PE}->\mathrm{SBC}->\mathrm{PLO}$ & 0,093 & 1,842 & 0,065 & {$[0,010 ; 0,212]$} & No & - \\
\hline $\mathrm{H}_{7}: \mathrm{PJ}->\mathrm{SBC}->\mathrm{PLO}$ & 0,161 & 2,143 & 0,032 & {$[0,030 ; 0,324]$} & Yes & $27 \%$ \\
\hline
\end{tabular}

Note: PU perceived usefulness; PE perceived ease; PJ perceived enjoyment; SBC student business competency; PLO perceived learning outcomes

From the results of the statistical test above, it can be proven in this study that Perceived Usefulness (PU), Perceived Ease (PE), and Perceived Enjoyment (PJ) have a significant positive effect on Student Business Competency (SBC). Hypothesis 1, namely perceived usefulness, has a positive influence on student business competency, indicating that business simulation class participants feel the benefits of facilitating understanding of 
theory and learning to increase participants' competence. Through the simulation, the participants make it easier to connect theory with practice in the business world so that this method is considered adequate and efficient in increasing participants' knowledge. The result in line with what (Hsu and Shiue, 2017) said that perceived usefulness affects student satisfaction with business simulation courses.

Perceived ease of use influences student business competency, learning conditions that are easy to understand and not complicated, often bring enthusiasm for participants to learn, and do not cause stress. Simulation learning uses a game approach; for young people, it tends to be easier to use technology, applications, and games, so learning using simulation games makes it easier for participants to learn. This result is following what was said by (Matute and Melero, 2019).

In hypothesis 3, namely perceived enjoyment influences student business competency. Learning to use games is often fun for everyone and encourages participants to enjoy the game process. Business simulation is a virtual game in the business process; when the activity attracts participants, it will encourage them to be involved and learn further to increase participant competence. The current generation $\mathrm{Z}$ students prefer to learn something in the form of a game so that it is more suitable for their daily lives who play more games.

Of the three proven hypotheses that proves that business simulation courses provide benefits for students when using the learning system, it is easy to use the simulation system, so that students believe the mental and physical effort required to use the system increases their competence and is an interesting activity, enjoyment it feels good to do it in education. These results are in line with research from (Hanafiah and Jamaluddin, 2018) which states that positive perceptions of ease of use, benefits obtained, attitudes and enjoyment of using simulations can improve test scores better. Thus, it is hoped that business simulations will continue to be provided in courses for students so that it supports students' understanding of business (Pratikto et al., 2019).

Student Business Competency (SBC) also significantly affects Perceived Learning Objectives (PLO). The students' competencies will support this course's learning objectives, which expects students to succeed with hard skills and soft skills such as student abilities to make decisions in a business (Levant et al., 2016) and management skills by involving them in business activities (Farooq et al., 2017). Through the learning process through simulations, students' soft skills improve, especially in communication, cooperation, and decision making for mutual success in the team. The result is also in line with what (Lohmann et al., 2019) states that business simulations contribute to student satisfaction by supporting learning outcomes related to management through socially constructed meanings. This conceptual contribution sheds further light on research and leads to educators' practical implications using simulation-based pedagogy. (Hernandes et al., 2019) confirm that crucial competencies such as information processing, cooperation, decision making, and agreement in uncertainty encourage learning achievement from a student perspective.

SBC is also able to mediate between PU and PJ on Perceived Learning Outcomes, but for PE it does not affect. It means showing that the benefits of learning and the convenience of participating in the learning process are essential factors in realizing learning objectives obtained from the increased competence felt by students. (Brown et al., 2018) stated that simulation provides learning opportunities for students that are less achievable through 
traditional classroom learning, especially in trying to connect business theory to practice and develop transferable skills such as time management, teamwork, communication, and presentation. (Gatti et al., 2019) state that simulations and games with cognitive and affective learning can influence students 'critical thinking skills and attitudes towards study sustainability and participants' interests. (Aries et al., 2020) that the learning process using games can increase motivation and influence student behavior to pay more attention to learning outcomes, including becoming entrepreneurs.

The results of this study are in line with (Farashahi and Tajeddin, 2018), which states that the theoretical basis of cognitive learning does not only focus on the static state of the trainees' knowledge but also on the dynamics of the knowledge acquisition process, organization, and application. Through simulations and case studies, there are two experiential learning methods where students get the opportunity to experience a dynamic domain in organizing, synthesizing, and applying the knowledge gained through lectures. As a generative learning process, simulation creates excellent opportunities for students to connect knowledge and experiential content and actively engage in understanding learning content. Through this process, students can actively develop managerial and interpersonal skills to generate a relationship between their knowledge and the real world.

\section{CONCLUSION}

The implication of this study results shows that Business Simulation is an important subject given to students of the Faculty of Economics and Business at Atma Jaya University. Educators and managers of educational institutions, especially management and business, need to continue developing learning methods that emphasize student center learning and apply more gamification models with attention to the competencies needed by the industrial world. The challenge is for educators to keep abreast of and study changes and technological developments.

This research has several limitations; the study was only conducted at the Faculty of Economics and Business in Atma Jaya University Jakarta. In measuring the competencies obtained using student perceptions, it had not considered the class's methodology and processes. For future studies, it is necessary to include a teaching methodology. Cajiao \& Burke (2016) state that instructional differences and instructors' and teachers' effectiveness can significantly provide differences in results. For this reason, future studies need to consider the factors of business simulation teachers and expand the coverage of respondents not only from business students.

\section{REFERENCES}

Aries, A., Vional, V., Saraswati, L., Wijaya, L and Ikhsan, R. (2020). Gamification in learning process and its impact on entrepreneurial intention.Management Science Letters , 10(4), 763-768. http://dx.doi.org/10.5267/j.ms1.2019.10.021.

Asiri, A., Greasley, A., and Bocij, P. (2017). A review of the use of business simulation to enhance students" Employability (WIP). (2017). Summer Computer Simulation Conference (SCSC). https://doi.org/10.22360/summersim.2017.scsc.039. 
Brown, D. M., Robson, A., and Charity, I. (2018). International masters' student perspectives of team business simulations. The International Journal of Management Education, 100268. https://doi.org/10.1016/j.ijme.2018.11.004.

Chai-Lee Goi. (2018). The use of business simulation games in teaching and learning, Journalof Education for Business, https://doi.org/10.1080/08832323.2018.1536028

Clarke, E. (2009). Learning outcomes from business simulation exercises. Education + training, 51(5/6), 448-459. https://doi.org/10.1108/00400910910987246.

Cohen, J. (2013). Statistical power analysis for the behavioral sciences. https://doi.org/10.4324/9780203771587.

Davis, F. D., Bagozzi, R. P., and Warshaw, P. R. (1989). User acceptance of computer technology: a comparison of two theoretical models. Management Science, 35(8), 982-1003. https://doi.org/10.1287/mnsc.35.8.98.

Dijkstra, T. K., and Henseler, J. (2015). Consistent and asymptotically normal PLS estimators for linear structural equations. Computational Statistics \& Data Analysis, 81, 10-23. https://doi.org/10.1016/j.csda.2014.07.008.

Farashahi, M., and Tajeddin, M. (2018). Effectiveness of teaching methods in business education: A comparison study on the learning outcomes of lectures, case studies and simulations. The International Journal of Management Education, 16(1), 131-142. https://doi.org/10.1016/j.ijme.2018.01.003.

Farooq, M. S., Salam, M., Jaafar, N., Fayolle, A., Ayupp, K., Radovic-Markovic, M., and Sajid, A. (2017). Acceptance and use of lecture capture system (LCS) in executive business studies. Interactive Technology and Smart Education, 14(4), 329-348. https://doi.org/10.1108/itse-06-2016-0015.

Gatti, L., Ulrich, M., and Seele, P. (2019). Education for sustainable development through business simulation games: An exploratory study of sustainability gamification and its effects on students' learning outcomes. Journal of Cleaner Production, 207, 667678. https://doi.org/10.1016/j.jclepro.2018.09.130.

Hair, J. F., Hult, G. T. M., Ringle, C. M., and Sarstedt, M. (2017). A Primer on Partial Least Squares Structural Equation Modeling (PLS-SEM), 2nd edition. Thousand Oaks: Sage.

Hair Jr, J., Sarstedt, M., Hopkins, L., and G. Kuppelwieser, V. (2014). Partial least squares structural equation modeling (PLS-SEM). European Business Review, 26(2), 106121. https://doi.org/10.1108/ebr-10-2013-0128.

Hanafiah, M.H. and Jamaluddin, M.R. (2018). Student Perception towards In-Class Simulation Games: A Case of Hospitality Investment Simulation. Journal of Tourism, Hospitality \& Culinary Arts, 10(1), 73-74.

Harold F. O'Neil, Eva L. Baker, Ray S. Perez. (2016). Using Games and Simulations for Teaching and Assessment: key issues. Ist edition. Routledge. https://doi.org/10.4324/9781315817767.

Hernández-Lara, A. B., Serradell-López, E., and Fitó-Bertran, À. (2019). Students' perception of the impact of competences on learning: An analysis with business simulations. Computers in Human Behavior, 101, 311-319. https://doi.org/10.1016/j.chb.2019.07.023.

Hsu, Y., and Shiue, Y. (2017). Understanding factors that affecting continuance usage intention of game-based learning in the context of collaborative learning. EURASIA 
Journal of Mathematics, Science and Technology Education, 13(10). https://doi.org/10.12973/ejmste/77949.

Jonathan, L. Y., and Laik, M. N. (2019). Using experiential learning theory to improve teaching and learning in higher education. European Journal of Social Science Education and Research, 6(1), 123. https://doi.org/10.26417/ejser.v6i1.p123-132.

Levant, Y., Coulmont, M., and Sandu, R. (2016). Business simulation as an active learning activity for developing soft skills. Accounting Education, 25(4), 368-395. https://doi.org/10.1080/09639284.2016.1191272.

Lim, D., and Rubasundram, G. A. (2018). Disruption in teaching \& learning: experiential learning and gamification in practice. Electronic Journal of Business \& Management, 1, 87-93.

Lin, H., Yen, W., and Wang, Y. (2018). Investigating the effect of learning method and motivation on learning performance in a business simulation system context: An experimental study. Computers \& Education, 127, 30-40. https://doi.org/10.1016/j.compedu.2018.08.008.

Lohmann, G., Pratt, M. A., Benckendorff, P., Strickland, P., Reynolds, P., and Whitelaw, P. A. (2018). Online business simulations: Authentic teamwork, learning outcomes, and satisfaction. Higher Education, 77(3), 455-472. https://doi.org/10.1007/s10734-018-0282-x.

Matute-Vallejo, J., and Melero-Polo, I. (2019). Understanding online business simulation games: The role of flow experience, perceived enjoyment and personal innovativeness. Australasian Journal of Educational Technology, 35(3). https://doi.org/10.14742/ajet.3862.

Mitchell, R. (2006). Custom vs evolved business simulations. Industrial and Commercial Training, 38(5), 248-250. https://doi.org/10.1108/00197850610677706.

Mohd Yatim, S., Goh, C. F., and Mohamad, R. Z. (2018). Factors influencing use of Monsoonsim business simulation by UTM undergraduate students. International Journal of Learning and Development, 8(2), 61. https://doi.org/10.5296/ijld.v8i2.13073.

Nitzl, C., Roldan, J. L., and Cepeda, G. (2016). Mediation analysis in partial least squares path modeling. Industrial Management \& Data Systems, 116(9), 1849-1864. https://doi.org/10.1108/imds-07-2015-0302

Pratikto, H., Wira Prabowo, S. H., Murdiono, A., and Basuki, A. (2019). The role of business simulator games implementation in improving the ability of analysis and business decision making independently for students (Literature research). KnE Social Sciences, 3(11), 1005. https://doi.org/10.18502/kss.v3i11.4067.

Zulfiqar, S., Sarwar, B., Aziz, S., Ejaz Chandia, K., and Khan, M. K. (2018). An analysis of influence of business simulation games on business school students' attitude and intention toward entrepreneurial activities. Journal of Educational Computing Research, 57(1), 106-130. https://doi.org/10.1177/0735633117746746. 